\title{
STUDIES ON PROTEIN SYNTHESIS
}

BY PROTOPLASTS OF SACCHAROMYCES CARLSBERGENSIS

\section{REVERSAL OF THE RNASE EFFECT ON PROTEIN SYNTHESIS BY POLYMETHACRYLIC ACID}

\author{
S. R. DE KLOET, R. K. A. VAN WERMESKERKEN AND V. V. KONINGSBERGER \\ Van't Hoff Laboratory, State University of Utrecht (The Netherlands)
}

(Received July i 4 th, I960)

\section{SUMMARY}

The ribonuclease inbibited protein synthesis and respiration of yeast protoplasts can be restored by the addition of several polyanionic compounds, among which polymethacrylic acid proved to be the most effective one.

The results of preliminary experiments with the ultracentrifuge indicate a strong complex formation between ribonuclease and polymethacrylic acid under the applied experimental conditions. It is suggested that the reversal of ribonuclease action by polymethacrylic acid in vivo may be attributed to such complex formation between ribonuclease and polymethacrylic acid.

\section{INTRODUCTION}

Several authors have reported an in vitro inhibition of ribonuclease by polyanions ${ }^{1-3}$. Heparine, polyvinylsulphate and polyphosphates were found to be rather effective inhibitors of RNase activity.

The present study deals with the reversal by polymethacrylic acid of the ininhibition by RNase of in vivo protein synthesis by protoplasts of yeast.

\section{MATERIALS AND METHODS}

Polymethacrylic acid was prepared according to ARNOLD AND OVERBEEK ${ }^{4}$; it was fractionated by $\mathrm{HCl}$ precipitation. The preparation used had a mol. wt. of approx. 50,0oo (see ref. 5), as measured by light-scattering.

Ribonucleic acid was prepared from yeast according to FISHER AND CHARGAFF ${ }^{6}$. It had an average mol. wt. of 40,000 , as estimated in the ultracentrifuge.

Abbreviations: PMA, polymethacrylic acid; RNA, ribonucleic acid; S-RNA, ribonucleic acid from the soluble $(\mathrm{I} 00,000 \times g)$ fraction of the cell; m-RNA, the ribonucleic acid from the microsomal particulate fraction; RNase, ribonuclease; DNA, deoxyribonucleic acid; AMP, GMP, CMP, UMP, adenosine, guanosine, cytidine, uridine monophosphate respectively. The $2^{\prime}, 3^{\prime}$ mixed and the $5^{\prime}$ phosphates were used. ATP, adenosinetriphosphate; TCA, trichloroacetic acid; PNPG, $p$-nitrophenyl- $\alpha$-D-glucoside. 
DNA was purified according to GULLAND ${ }^{7}$. Liver-s-RNA was prepared by phenol extraction of the $100,000 \times g$ supernatant of beef-liver homogenate according to $\mathrm{KIRBY}^{8}$, followed by dialysis at $4^{\circ}$ overnight and freeze drying.

Yeast-s-RNA was prepared in the same way.

The $2^{\prime}, 3^{\prime}$ mixed and $5^{\prime}$ mononucleotides and the ATP were products of Pabst.

The RNase digest of yeast RNA was prepared in the following way. I g RNA was incubated with I $\mathrm{mg}$ RNase in Io $\mathrm{ml} 0.05 M$ phosphate buffer $\mathrm{pH} 7.4$ at $37^{\circ}$. After $4 \mathrm{~h}$ the solution was dialysed against $20 \mathrm{ml}$ water for $\mathrm{I} 4 \mathrm{~h}$ at $0^{\circ}$. The dialysate was freeze dried.

Ribonuclease was assayed according to Kalnitsky et al ${ }^{9}$. All other materials and methods were the same as described before ${ }^{10}$.

\section{EXPERIMENTAL RESULTS}

\section{Reversal of the RNase effect on protein synthesis by PMA}

When yeast protoplasts are incubated with RNase, protein synthesis is inhibited $^{10}$. Several polyanion compounds and mixtures of nucleotides were tested for their ability to reverse this inhibiting action of RNase (Table I).

TABLE I

REVERSAL OF THE INHIBITION BY RNASE OF [14C]AMINO ACID INCORPORATION

Protoplasts ( $2 \mathrm{mg}$ protein $/ \mathrm{ml}$ ) were incubated with $50 \mu \mathrm{g} \mathrm{RNase} / \mathrm{ml}$ for $30 \mathrm{~min}$ at $30^{\circ}$ in $10 \mathrm{ml} 10 \%$ mannitol containing $50 \mu$ moles $\mathrm{K}-\mathrm{Na}-\mathrm{PO}_{4}$ buffer $\mathrm{pH}$ 6.8. After repeated washings, the protoplasts were incubated with a $0.5 \%$ solution of the compounds listed in the Table and tested for their ability to incorporate $\left[{ }^{\mathbf{1 4}} \mathrm{C}\right]$ valine as described previously ${ }^{\mathbf{1 0}}$.

\begin{tabular}{lrc}
\hline \multicolumn{1}{c}{ Compound added } & $\begin{array}{c}+ \text { RNase } \\
\text { counts/min/mg }\end{array}$ & $\begin{array}{c}- \text { KNase } \\
\text { counts/min/mg }\end{array}$ \\
\hline Yeast RNA (comm) & 4 & 292 \\
RNase digest of yeast RNA & 94 & 326 \\
Liver-s-RNA & 94 & 298 \\
DNA & I $^{25}$ & 245 \\
Mixture of $2^{\prime}, 3^{\prime}$ nucleotides & 58 & 190 \\
Mixture of $5^{\prime}$ nucleotides & 35 & 385 \\
PMA & 375 & 264 \\
\end{tabular}

The results of Table I show that polymethacrylic acid is highly effective in restoring the RNase-inhibited incorporation of amino acids by protoplasts of Sacch. Carlsbergensis.

Table II shows some results of experiments when protoplasts were incubated with RNase and PMA at the same time.

It can be seen that the inhibition of $\left[{ }^{11} \mathrm{C}\right]$ leucine incorporation by RNase is markedly decreased in the presence of PMA.

Not only unspecific protein synthesis (amino acid incorporation into TCA-insoluble protein), but also the induced specific $\alpha$-glucosidase synthesis was restored by addition of polymethacrylic acid (Fig. I).

From the experimental results as shown in Fig. $I$ it can be concluded that the RNase-inhibited $\alpha$-glucosidase synthesis is also restored by the addition of PMA. 
TABLE II

THE IFFECT OF RNASE ON THE INCORPORATION OF [14C]LEUCINE IN THE PRESENCE AND ABSENCE OF PMA

Protoplasts ( $2 \mathrm{mg}$ protein $/ \mathrm{ml}$ ) were preincubated with RNase at $30^{\circ}$ for $20 \mathrm{~min}$ in $10 \%$ mannitol containing $50 \mu$ moles $/ \mathrm{ml} \mathrm{Na-K}-\mathrm{PO}_{4}$ buffer $\mathrm{pH} 6.8$, before Io $\mathrm{mg} \mathrm{PMA} / \mathrm{ml}$ and $\left.{ }^{[14} \mathrm{C}\right]$ leucine (20,000 counts/min) were added.

\begin{tabular}{|c|c|c|}
\hline Concn. RNase/ml & $\begin{array}{c}-+P M A \\
\text { counts!min/mg }\end{array}$ & $\begin{array}{c}-P M A \\
\text { counts } / \mathrm{min} / \mathrm{mg}\end{array}$ \\
\hline 0 & 5000 & 4353 \\
\hline 20 & 3060 & 92 \\
\hline IOO & I 336 & 38 \\
\hline
\end{tabular}

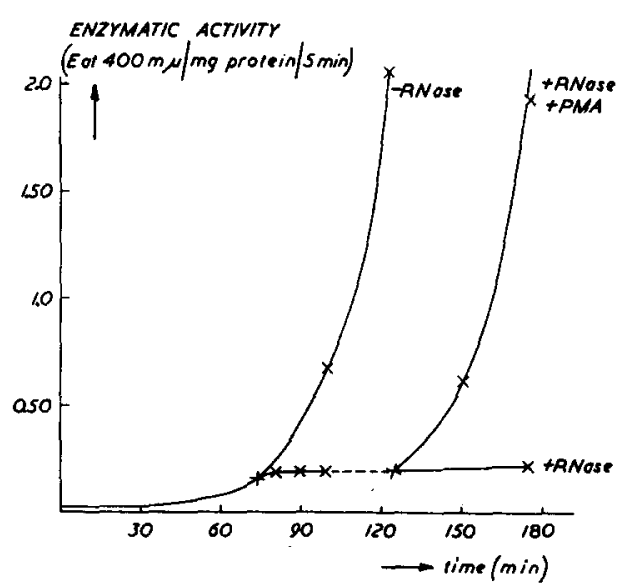

Fig. I. Reversal by PMA of the inhibition by RNase of $\alpha$-glucosidase synthesis by yeast protoplasts. Protoplasts were adapted to maltose for $75 \mathrm{~min}$ at $30^{\circ}$ in a $0.5 \mathrm{M}$ phosphate buffer $\mathrm{pH} 6.2$; then $0.75 \mathrm{mg}$ RNase was added to $7.5 \mathrm{ml}(3 / 4)$ of the sample. The remaining $2.5 \mathrm{ml}$ were diluted to $10 \mathrm{ml}$ with the same adaptation medium ${ }^{10}$. This portion was used as the blank without RNase. The RNase was allowed to react for $25 \mathrm{~min}$, the protoplasts being washed by centrifugation afterwards. The cells were divided into two equal portions, each being resuspended in adaptation medium to a final volume of $10 \mathrm{ml}$. In one case the sample was supplemented with $100 \mathrm{mg}$ PMA. The other was the RNase blank. Samples were withdrawn at appropriate times to test for $\alpha$-glucosidase activity ${ }^{10}$.

Attention may be drawn to the fact that $\alpha$-glucosidase synthesis starts immediately after the addition of PMA without any preceding lag-time.

\section{Studies on the interaction between PMA and RNase}

Experiments were performed to investigate the direct effect of PMA on RNase activity as well as the nature of the interaction between PMA and RNase.

It could be shown that under the experimental conditions PMA inhibits the ribonuclease activity as determined according to KALNITSKY to some extent (Fig. 2). 
As is shown in Fig. 3, sedimentation experiments in the Spinco analytical ultracentrifuge indicate a strong complex formation between ribonuclease and polymethacrylic acid at $\mathrm{pH} 6.8$.

Under the experimental conditions, the polymethacrylic acid used had a sedimentation constant of I.2 S units; when polymethacrylic acid and ribonuclease are centrifuged together, a peak is found with a sedimentation constant of I.9 S units, indicating a complex formation between RNase and PMA. This may be attributed to the high positive charge of RNase (isoelectric point at $\mathrm{pH} 9.45$ ) and the negative charge of PMA at $\mathrm{pH} 6.8$.

Finally, it is shown that PMA is also effective in restoring the RNase inhibited glucose respiration (Fig. 4).

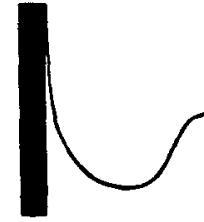

A

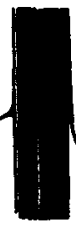

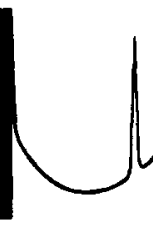

B

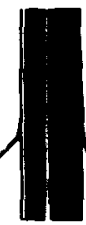

patterns. A, ribon clease $0.4 \%, 130 \mathrm{~min} 59,780 \mathrm{rev} / \mathrm{min} ; \mathrm{B}$, poly methacrylic acid $0.4 \%, 129$ min 59,780 $\mathrm{rev} / \mathrm{min}$; $\mathrm{C}$, polymethacrylic acid $0.4 \%$ and ribonuclease $0.4 \%$, I 30 min $59,780 \mathrm{rev} / \mathrm{min}$. All compounds were dissolved in a medium containing ro\% mannitol, $0.05 M$ phosphate buffer $\mathrm{pH} 6.8$.

Fig. 4. Reversal by PMA of the RNase effect on aerobic glucose dissimilation. Protoplasts $(5 \mathrm{mg}$ protein $/ \mathrm{ml}$ ) were preincubated in Warburg vessels with $20 \mu \mathrm{g}$ RNase $/ \mathrm{ml}$ in $\mathrm{I} .5 \mathrm{ml} 10 \%$ mannitol containing $50 \mu$ moles $\mathrm{K}$-Na-phosphate buffer $\mathrm{pH} 6.8 / \mathrm{ml}$. After $30 \mathrm{~min}$ at $30^{\circ}, 0.2 \mathrm{ml} \mathrm{10 \%}$ PMA in $10 \%$ mannitol was added from one side arm and $0.2 \mathrm{ml} 10 \%$ mannitol containing 10 moles glucose from the other. $\oplus$, no RNase; 田, $20 \mu \mathrm{g} \mathrm{RNase} / \mathrm{ml}$ + $\mathrm{ro} \mathrm{mg} \mathrm{PMN} / \mathrm{ml} ; \times, 20 \mu \mathrm{g}$ RNase $/ \mathrm{ml}$.

\section{DISCLSSION}

A number of data has been published, indicating the reversal by high molecular weight anions of RNase and DNase inhibition of some cellular and subcellular activities.

AllFREY AND MIRSKY ${ }^{1}$, when studying amino acid incorporation in the protein of the cell nucleus have observed that the inhibition which resulted from incubation of cell nuclei with DNase could be reversed by the addition of polyanions such as heparine etc. Isolated mitochondria ${ }^{11}$, when treated with ribonuclease are no longer able to carry out oxidative phosphorylation. This phenomenon could also be reversed by some polyanionic compounds.

Our experimental data show that the RNase inhibited protein synthesis ${ }^{\mathbf{1 0}}$ by protoplasts of yeast is restored upon the addition of a number of compounds. This reversal is most effective when polymethacrylic acid is used.

In vitro, RNase activity is also inhibited by PMA. Ultracentrifuge patterns of RNase, PMA and RNase + PMA indicate a rather strong complex formation between 
PMA and RNase under the applied experimental conditions. Consequently, the action of PMA on RNase activity in vivo may be binding by complex formation, keeping the RNase from further action inside the protoplast, thus restoring RNase inhibited cellular activities such as respiration and protein synthesis. Still, the observed instantaneous reversal of RNase action by PMA is rather unexpected as the only direct action known of this enzyme--the breakdown of RNA-is supposed to be irreversible.

\section{ACKNOWLEDGEMENTS}

The authors wish to thank Prof. Dr. J. Th. G. Overbeek for his stimulating interest and helpful criticism during the course of their work.

This work was supported by a grant from the Stichting Scheikundig Onderzoek in Nederland.

\section{REFERENCES}

IV. G. Allfrey and A. E. Mirsky, Proc. Natl. Acad. Sci. U.S., 44 (I958) 982.

2 M. Nomura, J. Hosoda and S. Nishimura, Biochim. Biophys. Acta, 29 (I958) i6r.

${ }^{3}$ L. Vandendriessche, Arch. Biochem. Biophys., 65 (19.56) 347.

4 R. Arnold and J. Th. G. Overbeek, Rec.trav. chim., 69 (I950) 192.

5 A. VRIJ, Thesis, Utrecht, I959.

${ }^{6}$ E. Fischer and E. Chargaff, J. Biol. Chem., i 76 (1948) 7 I 5.

7 J. M. Gulland, J. Chem. Soc., (1947) i 129.

8 K. S. KirbY, Biochem. J., 64 (1956) 405.

${ }^{9} \mathrm{G}$. Kalnitsky, J. P. Hummel and C. Dierks, J. Biol. Chem., 234 (I959) i 512.

10 S. R. De Kloet, R. K. A. van Wermeskerken and V. V. Koningsberger, Biochim. Biophys. Acta, 47 (196r) I 38 .

11 J. B. Hanson, J. Biol. Chem., 234 (1959) 1303. 